\title{
Women Who Participate in Illegal Pyramid Selling: Voices from Female Rural Migrant Offenders in China
}

\begin{abstract}
Anqi Shen ${ }^{1}$
Received: 7 December 2018 / Accepted: 7 August 2019 / Published online: 31 August 2019

(C) The Author(s) 2019
\end{abstract}

\begin{abstract}
Mainly through a case study, this article examines Chinese women's involvement in one form of organised crime - illegal pyramid selling — which is increasingly prevalent among female offenders in recent years in China. The article discusses the socioeconomic context to situate the findings and introduces the research methods and data. It then details the case study discussing the following: first, the nature of pyramid schemes and the Chinese law concerning the illicit business; second, migrant women's entry into illegal pyramid selling and their motives; and third, the roles that women play in the criminal operations. In addition, women's gains and losses as a result of participation in the crime are explored. Finally, it concludes the article by highlighting the empirical evidence presented and offers implications of the research.
\end{abstract}

Keywords Women · Internal migration · Organised crime $\cdot$ Pyramid selling · China

\section{Introduction}

Organised crime has drawn increasing attention of academics, enforcement agencies, policymakers, journalists and the general public, although what organised crime really is remains contested (Wright 2006). Much work has been done to investigate criminal groups and networks typically in the context of transnational organised crime, because there appears to be a linkage between transnational organised crime, modernity and globalisation (see Allum and Gilmour 2012). Organised crime research has also focused on criminal enterprise and the criminal markets (e.g. Antonopoulos 2016; Hobbs 1988). Existing literature suggests that the scope of organised crime is broad and continues to expand, and that organised crime is diverse, multifaceted and fast changing, encompassing traditional organised criminal activities - such as protection rackets, extortion and loan sharking - to modern day criminal enterprise.

Anqi Shen

anqi.shen@northumbria.ac.uk

1 Northumbria Law School, Faculty of Business and Law, Northumbria University, Newcastle Upon Tyne NE1 8ST, UK 
Organised crime, in whichever form, requires a degree of organisation, coordination and exchange of money and services between criminal players.

Past research on organised crime typically neglected women as perpetrators, despite that women are not invisible in planning criminal activities and conducting serious crimes with accomplices (e.g. Brownstein et al. 1995; Miller 1998). The neglect of women in organised crime research is not surprising because criminology has long been 'androcentric' (ChesneyLind 1989), dominated by male offenders and ignoring women. In recent decades, there has been increasing work examining women in crime as perpetrators. Along with this trend, academic research started to pay attention to women in criminal groups and organised criminal activities. Focuses include females' roles in youth gangs (e.g. Aldridge and Medina 2008; Batchelor 2009; Chesney-Lind 1993; Miller 2001), Mafias (e.g. Dino 2012; Fiandaca 2007) and transnational organised crime (see e.g. Special Issue in 2014 on women in transnational organised crime in Trends in Organised Crime). Notably, organised crime research is often based on the experiences of women in the North of the Globe (major countries in North America, Western Europe and Britain) whilst women in the Global South are typically underrepresented. The problem is not unacknowledged. An ambitious project was conducted in 2000, which aimed to map out the role of women in organised crime over a 20-year period across the globe (Fiandaca 2007). It concluded with publication of research findings in some countries participated in the study but left 'gaping holes' in the 'map' (Pizzini-Gambetta 2008), in which China was not included.

English language literature about Chinese women's involvement in organised crime is sparse. In transnational settings, past research has remarkably investigated women in human smuggling from China to the USA, both as smugglers and 'trafficked victims' (Chin and Finckenauer 2012; Zhang et al. 2007b). In regard to mainland China, previous studies have looked at internal migrant women in the sex industry mainly as sex workers (e.g. Liu 2012; Zheng 2009) and women as victims in internal human trafficking (Chu 2011; Zheng 2014). More recent research (see Shen 2015) has paid attention to Chinese women as perpetrators in the black-society style criminal organisations, sex work management and internal child trafficking. These studies highlight the visibility of women in organised crime. It is pointed out that given their socioeconomic conditions - resource deficiencies in particular-rural-tourban migrant women tend to be susceptible to deviance and crime (Liu and Peng 2012). However, existing research on women in organised crime is rather limited, and therefore more nuanced and in-depth analysis is needed. The present study is hoped to make a contribution to the literature in this area.

Mainly through a case study, this article examines Chinese women's involvement in one form of organised crime - illegal pyramid selling — which appears to be increasingly prevalent among female offenders in China (see Shen 2017). Following an introduction, which provides the background and rationale of the research, it discusses the socioeconomic context in the reform era in China, to situate the empirical findings about women's participation in criminal enterprise. Next, it introduces the research methods and data. It then details the case study discussing the following: first, the nature of pyramid schemes and the Chinese law concerning the illicit business; second, migrant women's entry into illegal pyramid selling and their motives; and third, the roles that women played in the criminal operations. In addition, women's gains and losses as a result of their lawbreaking are explored. Finally, the article concludes by highlighting the empirical evidence presented and offers several implications of the research. The article aims primarily to exhibit women's participation in criminal enterprise and is essentially a Chinese case study concerning gender dynamics presented in organised 
crime. To a lesser extent, it explores the impact of social exclusion, and class and gender inequalities on rural migrant women. Due to the global nature of organised crime and migration, the regional context, in which this study took place, has a broad international significance in the fields.

We will see later that the participants in this study were recruited for a different research project, who were convicted female migrant offenders. I therefore provide some background information in the following pages, to explain social identity of rural migrant women to help a better understanding of some of the findings.

\section{Internal Migration, Inequality and Female Rural Migrants in China: Some Background}

Internal mass migration is an inevitable movement in China, following the economic reforms started in the late 1970s, which began market economy in the world's largest socialist country. In the reform era, China is undergoing unprecedented urbanisation and industrialisation. Millions of people, mainly surplus rural labourers, move from the countryside into economically developed urban areas every day (Miller 2012). According to the China Labour Bulletin (2018), as of the end of 2017, there were officially over 286.5 million migrant peasant-workers (nong-min-gong), who were registered as rural residents, living in urban China (see also Xinhua News 2018a). Internal mass migration has profound implications for the urban social structure and economy. Two points are relevant to deviance and crime: first, public policy that results in the exclusion and discrimination against rural migrants in society; second, structural factors that make individuals in disadvantaged socioeconomic groups susceptible to lawbreaking.

The policy that institutionalised the rural-urban divide started in Mao's socialist China and remains effective today. In the context of international migration, immigration law and enforcement are mechanisms of control in the host countries. In a similar vein, to respond to the potentially massive human movement in China, hukou — the household registration system — was introduced as a form of migration control. The hukou system has rendered considerable differences between villagers and urbanites, with urban hukou holders enjoying the state-sponsored benefits, rights and privileges, to which the rural Chinese are not entitled (Rofel 2007). It is clearly a root cause of the rural-urban inequality. Consequently, rural migrants suffer from multi-dimensional exclusion in cities (Xu 2014). At the same time, the rural-to-urban migration is viewed as a cause of tremendous pressure in urban China, especially social unrest and the rise of crime (Li 1996; Zhang 2001). Like international immigrants (see e.g. Pratt and Valverde 2002), internal migrants in China are often depicted as criminals and security threats, and thus subject to criminal prevention strategies. Internal migration was, and remains, 'a live issue' (Davin 1999). Rural migrants, as a socioeconomic group, are systematically underprivileged.

Capitalism, on the one hand, may have attributed to China's remarkable economic success in the past forty years, but, on the other, has also made it an ever-polarised society (Yan 2009). For Wang (2003), the traditional urban-rural inequality has transformed into disparities in income among different classes, with a small number of super-rich at the top, and millions of migrant workers and the rural population at the bottom, some of whom are still in impoverished conditions (Naughton 2007). Migrant offending may be a manifestation of social inequality in today's neoliberal China. In free market economy, people are increasingly mobilised and individuals are encouraged to engage in all kinds of entrepreneurial activities to generate wealth, whilst resources are unevenly distributed in society (Bakken 2018; Harvey 2005). The under- and working classes, to which rural migrants belong, are disadvantaged in 
the money-making process and left behind by their fellow urban citizens. Whilst opportunities are shut down to them in the legitimate world, doors are readily open in the criminal markets (Shen and Antonopoulos 2016). This is in fact not new, and Merton (1938) would call it 'deviance innovation' which involves (socially disadvantaged) individuals who attempt to achieve a culturally approved goal (monetary success) by unconventional means (criminal offending).

Women, of course, are part of the internal migration movement, who flow into cities to look for opportunities among thousands of migrant workers. In the city, plentiful jobs with low rates of pay await rural migrant women, who typically have no qualification, particular skills and social capital. They often find jobs in low-wage employment sectors (Cartier 2001), including labour-intensive industries (Ngai 2007), domestic services (Rofel 2007) and the sex industry (Liu 2012; Zheng 2009). Often, because of their socioeconomic status, female migrants are subject to the super-exploitation of labour power (Harvey 2005).

The reality for Chinese women appears to be contradictory. China proclaimed gender equality as an important public policy from the early days of the founding of the People's Republic, and Mao himself promoted radical feminism in the socialist era (Freitag 2010). As a result, women are expected to go out to work and make an equal contribution to family income. In market economy, they are increasingly expected to compete with men in wealth generation (Shen and Winlow 2013). However, Chinese women's emancipation is not without conditions. The fact is that inequalities for women are not only gendered, but also classed and generational: in the job market, compared with men, women have fewer opportunities (Attané 2012), and compared with their better qualified and well-resourced urban sisters, rural women are much less competitive. The gendered and classed social conditions generate enormous pressure on women, and migrant women in particular (Shen 2015; Sun et al. 2016) whom are profoundly marginalised in urban society. It is suggested that marginalisation makes individuals vulnerable and prone to criminal offending (Bakken 2005).

Connection between migration and crime is not new (see e.g. Marshall 1997; Melossi 2015; Palidda 2011; Tonry 1997). In international research, there is a long history of linking migrants to disorder and crime. Migrant criminality is often analysed for the purpose of shaping national policy on immigration (Aliveti 2013); academically, the subject matter is rigorously studied to advance scholarship on inequalities, social exclusion and crime control (see Aas and Bosworth 2013). In China, past research in regard to migration, deviance and crime has examined drug problems among migrant youths (Liu, 2011), as well as inadequacy in public policy in response to rural migrants' problems which are viewed as structural factors for migrant offending (Lo and Jiang 2006; Zhao and Kipnis 2000). Moreover, previous studies have also applied existing theories to examining migration and crime in China, to test the established propositions or to make sense of the change of crime patterns in the reform era (e.g. Cheng et al. 2017; Liu 2005; Xu 2009, 2014; Zhang et al. 2007a). So far, little has been done to explore the subjective experience of migrant offenders; and, migrant women's involvement in urban crime is largely neglected. This study - which investigates female migrants' participation in criminal enterprise-is hoped to fill in some of the gaps.

\section{Methods and Data}

The data used in this article was drawn from a larger project on internal migration, crime and punishment in China (Shen 2018), which took qualitative approaches to the collection of 
original data. That was because qualitative research focuses on the subjective meaning of individual experiences and helps to gain rich exploratory insights into women's life stories (Hesse-Biber 2007). The sample was recruited from a large prison in a southeast region in China, with which a female unit was affiliated but operated by female staff in a separate locality.

The fieldwork was undertaken in the female unit in May 2016. Semi-structured interviews were conducted to gain female migrant offenders' narratives and biographies. Eleven women prisoners who were rural-to-urban migrants participated in the interviews. Each of them was fully informed of the voluntary nature and confidentiality of the research. Interviews were undertaken in a large activity room within the female unit, where confidentiality was guaranteed. The interviews lasted between thirty minutes and around one hour and were recorded by note-taking. The field notes were word-processed and simultaneously translated from Chinese into English after the interviews on the same date. Data was manually processed, and the interviews were analysed one by one to identify emerging themes presented by the participants.

The female migrant offenders in this sample ranged in age between 23 and 51, of who the majority were in their twenties. The women's educational status is remarkably diverse: from high to low, four women were senior college graduates who had an adequate qualification; one was junior college graduate and thus had basic education; five were undereducated - being primary school graduates and dropouts - and one was illiterate. As to employment, among the 11 participants, five were employed, including three employees of the 'criminal firms' (which are ostensibly legitimate companies but conduct systematic criminal activities in the commercial setting) and two service workers in the entertainment industry; two women were selfemployed; and four were unemployed. As Table 1 illustrates, the female participants were involved in six types of crime. None of them had a criminal record previously.

This article is mainly based on data drawn from a case study, as well as secondary data (knowledge and information gathered from published materials and open sources). Case study is often recognised as a research design that targets no particular data collection method (Yin 2009). For Hartley (2004), case study is a research method and also a design of its own right. Case study research typically allows for in-depth review of new or unclear phenomena whilst 'retaining the holistic and meaningful characteristics of real-life events' (Yin 2009: 4). Robert Yin (2009) - a world-renowned authority in case study research design - points out that rigorous data can be obtained through case study; there is no hard rule as to how many cases are sufficient for case study research to be rigorous or valid. In fact, a body of outstanding

Table 1 Type of offences involving female participants $(n=11)$

\begin{tabular}{lll}
\hline Type of crime & Participant & $\begin{array}{l}\text { Representation in female } \\
\text { participants }(\%)\end{array}$ \\
\hline Personal Crimes & 1 & 9.0 \\
False imprisonment (illegal pyramid selling related) & 1 & 36.4 \\
Property Crimes & 4 & \\
Fraud & 3 & 45.6 \\
Theft & 1 & \\
Regulatory crimes & 6 & \\
Leading and organising illegal pyramid selling & 1 & \\
Prostitution-related offences & & \\
Sheltering others for drug use & 3 & 100 \\
Total & 2 & \\
\hline
\end{tabular}


feminist research has drawn from case study, such as Ngai's (2007) work in which the case of a few factory female workers was employed.

In this article, I chose the case of women involved in pyramid selling for further analysis for two major reasons. First, it is observed that women today may play a leading role in economic crimes, such as pyramid selling and illegal fund-raising (see e.g. Shen 2017). Typically, illegal pyramid selling is operated by criminal enterprises and thus a form of organised crime. At the same time, we know little about women's involvement in it. The case study was considered allowing a detailed inquiry. Second, it is quite telling that two women were convicted of or in relation to pyramid selling in this random but small sample of 11 female participants. They were engaged in two different pyramid schemes but played a similar role. It therefore appears to be a 'typical case sample' (Withrow 2014) which enables some insights to be gain (Layder 2013).

There are two types of limitations in this study. The first is 'internal validity' in relation to interview data in general (Jacques and Wright 2014). In addition to 'impression management' (Goffman 1959) participants may lie or provide reconstructed, vague or seemingly distorted accounts (see, Sharpe 2012; Shen 2015). This limitation should be offset by the fact that the participants did not participate in the same pyramid scheme, but their accounts of the type of criminal enterprise and their involvement in it were largely consist and thus support each other. The methodological triangulation (Denzin 1978) was also of assistance. As we will see shortly, the secondary data was used to verify what was said by the participants in the case. The limitation should be minimised also by ensuring and reassuring confidentiality and anonymity before and during each interview. To fulfil this obligation, all names of participants and places in this article are pseudonyms. It is worth noting that peer review - as an important measureshould be adopted to ensure reliability and accuracy of data. However, the interviews, from which the original data was drawn, were undertaken in the prison environment where what an external researcher can do is considerably restricted. (Shen 2015). Consequently, peer review was not practically possible.

In interview research, biases may, of course, come from researchers themselves (Willis 2007). Previously, academic researchers, such as Hall et al. (2008), have considered what interpretivists claim. For these established scholars, the reality as we know is socially constructed and the researchers' own pre-existing thoughts and views about the research subject inevitably influence and shape research itself. Glaser (2007) went further and argued that there is no such thing as bias, or objective or subjective, and so on; data is what the researcher is receiving as a human being. Learning from Hall et al. (2008), I attempted to remain true to the data as it was spoken and report the findings as accurately as possible to maximise the validity and credibility of the research.

The second limitation is the 'generalisability issue', with qualitative studies based on a smaller number of participants. Jacques and Wright (2014) convinced us that whilst qualitative research - as compared with typical quantitative studies - may naturally raise questions about the validity and generalisability of findings, it does have its own merits. In the current study, a sample of 11 participants does appear to be small. Given the small sample size and the case study of two women, to generalise about all female offenders in illegal pyramid selling is a risk. However, the focus here is on the participants in the case, to aim to understand in great detail their experiences to gain an insight into women's involvement in the criminal enterprise. In addition, the participants and their experiences in the illicit business are by no means atypical. In this context, the use of data here should be valid and the findings should have wider value and applicability, which obviously can be tested in future studies. 
It is worth repeating that the interviews were conducted in the prison environment in a country where access to prisoners is extremely difficult and where fieldwork is restricted with conditions. The evidence gathered in this exploratory study should serve as a starting point to inspire future even more rigorous research.

\section{Case Study: Migrant Women Who Are Involved in Illegal Pyramid Selling (chuan-xiao)}

Media sources reveal that pyramid selling (also known as 'pyramid schemes' or 'chain selling') is rampant in China (e.g. Caixin 2017; Xinhua News 2018b). It was illustrated that around 280,000 cases involving illegal pyramid selling were sanctioned by the Administrative Authorities for Industry and Commerce in 2014 (Zhi and Hong 2015), and 2826 pyramid schemes were investigated by the police in 2016 (Global Times 2017). On 8 May 2018, a criminal group running Yun-lian-hui - a large-scale pyramid scheme operated in Guangzhou - was cracked down by the authority and a number of arrests were made (Xinhua News 2018c). Therefore, pyramid selling is a contemporary, questionable business practice and may amount to serious crime in China.

\section{Nature of Pyramid Schemes and the Chinese Law Concerning Illegal Pyramid Selling}

The law that criminalises chuan-xiao was created in 2009, as part of the Amendment VII of the Chinese Criminal Law 1997. It was asserted in Article 224 in Section 8 'Crimes of Disturbing the Order of the Socialist Market':

It is a criminal offence that a person organises or leads pyramid selling to cheat the members of the pyramid scheme over their property and disturb the economic and social order, in which the person, in the name of marketing goods, offers services or any other business and requires potential members - by paying a fee or any other means - to obtain the eligibility to participate in purchasing the goods or services; in which the members are classified into multiple levels in accordance with a certain order, and obtain remunerations or kickbacks that are calculated directly or indirectly based on the number of new members whom they recruit.

A person, who induces or coerces the members to continue recruiting others to participate in pyramid selling, is punishable with under 5 years imprisonment or criminal detention and a fine; in serious circumstances, 5 years or a longer fixed-term imprisonment [emphasis added].

This provision specifies modus operandi and the deceitful and collective nature of the criminal act. The law reads awkward even in its original form, due to the complexity of the illicit business. ZJ - a 23-year-old young woman originally from a village in Shaanxi-offered a detailed illustration:

Our project was called zi-ben-yun-zuo (capital operation) and was a kind of investment product. It was imported from a foreign country, and now similar schemes are running in almost all of the provincial capitals [in China]. Simply speaking, it involved capital accumulation and then reallocation. What it was intended for was to keep the proceeds within an enclosed circle and eventually all members would get rich ... Newcomers 
must pay an entry fee of 70,000 yuan to join and were then paid a fixed amount of salary for the first month. Once the entry fee was paid, you could start to recruit xia-xian (lower level members) and get fen-hong (dividends). Our company adopted a three-layer system, which meant that you could get dividends from up to three levels of members below you. Obviously, the more you recruited, the more dividends you got, and the higher your position would be in the structure....

The ultimate goal of everyone in the scheme was to chu-ju (exit) because once you were out, you could take your money and go. There were two ways of exiting the scheme. First, you could zi-ran-chu-ju (natural exit) once you have earned ten million yuan. That was the best way out. The second was $t i-c h u$-ju (being kicked out). This would happen when, for example, members had sexual affairs or the creditor-debtor relationships between them, which was strictly prohibited in our company. Natural exit meant that you had made a lot of money, with which you could start up a business, say, to open a shop, or you might become one of the scheme organisers if you were invited...

This extract of the record of interview with the female migrant offender shows the complexity of a pyramid scheme, as well as how seemingly legitimate and appealing it may look. As we can see, ZJ's company operated chain-selling of an 'investment product', of which high returns were expected. It is in fact a scam virtually identical to that Shen (2016a: 81) identified. It is pointed out that the operation of a pyramid scheme is often described as fair, transparent and economically viable to potential members (investors). Consequently, many people voluntarily join chain selling and they often deny being tricked when law enforcement intervenes (Yang 2011).

ZJ was one of these people. She willingly joined the pyramid scheme, fairly successfully persuaded others to participate in and denied the illegality of the criminal market activity, even at the time of interviewing after having been convicted of lawbreaking. Clearly, the young woman was employed by a criminal firm, which appeared to be legitimate, with usual corporate governance in place - including formal organisational rules and procedures - but in fact systematically carried out illicit business operations. For ordinary members of a pyramid scheme, such as ZJ, business practices in these companies may look absolutely normal. ZJ's account was supported by ZYY - another young woman who worked in a company running a similar scheme for over a year, which she did not find different from any other (legitimate) firm. It appears that the migrant women were involved in a type of 'corporate crime' which is enacted by collectivities (Gottschalk 2012: 364) in the criminal markets. However, compared with criminal opportunities and practices typically proliferating in the criminal underworld (Steffensmeier 1983), pyramid selling is more disguised of its real nature; and, like financial crime, it is profit-driven.

As noted earlier, illegal pyramid selling is a newly created crime in China. It is defined by legislation which, as any other regulatory crime (see Ashworth 1991), may not be regarded as 'real' crime. Thus, the law concerning it may be breached by those otherwise law-binding citizens who do not, or may not be able to, comprehend the nature of the criminal operation. Here, ZJ insisted in the interview that had the police not had interfered, she would possibly have got the money and naturally exited. Although the knowledge of legality is irrelevant as far as the law is concerned, this explains why the female lawbreakers in the case study did not show much remorse, nor did they admit guilt, as women offenders usually do (Steffensmeier and Allen 1996).

The fact is that a pyramid scheme involves 'capital operation' that cannot last for long. Only a few on the top of the pyramid may gain, whilst the vast majority of the members will lose at some point (Zhi and Hong 2015). Unfortunately, this is not usually understood by those participating in pyramid schemes, who typically want to make quick money by doing little 
(Nie 2016; Yang 2011). Failure to identify the harm that follows illegal pyramid selling often renders the 'economic cult' (Yang 2011) to attract people - often rural migrants (Shi and Cao 2013) _ as a money-making mechanism, or a career opportunity, or both. This is taken advantage of by 'the few' - criminal organisers - on top of the pyramid. Ordinary members of pyramid selling - including the rural migrant women in this case study who performed an active role in the pyramid schemes - were de facto victims and often made substantial losses, as we shall see later in this article.

\section{Migrant Women's Entry into Illegal Pyramid Selling and Their Motives}

In the interviews, I asked the female participants how they got involved in pyramid selling in the first place. Here was the answer from ZYY, who was 26-year-old, originally from a village in Fujian and a junior college graduate:

... I initially had a job in a factory making magnet boards. It was low-paid, and I did babysitting in my spare time to earn a little more. The factory job had absolutely no prospect and I left after being there for three years. Then I worked as a sales assistant in a small shop selling ladies' underwear... There I befriended a man in 2014, who told me that he was working at a large corporation in the fashion industry in a provincial capital and that I'd have a better job there. I went with him... I found that they were actually doing pyramid selling... The friend convinced me that I would have loads of money after several years... It was tempting... The situation in my family was not good: my mum was severely injured a few years ago and is unable to work...

It appears that ZYY joined the pyramid scheme as a result of misrepresentation and later was motivated by the potential gain to take part in it. ZJ, who was a college graduate with a certificate in computerised accounting, found the job advertised online, which was recruiting a qualified accountant. These are common experiences of individuals who are involved in illegal pyramid selling (see Xinhua News 2018b). For ZJ, the post, which required a suitable candidate to be able to assist with accounting and finance, training and general management within the company, was ideal: 'these are what I dreamed to do...', and 'it's a kind of job that it is not usually available to someone like me, who does not have a university degree'. She was probably right. In China, a senior college certificate is certainly not enough for a white-collar job that may potentially take the candidate to a higher management floor.

The interviews with the rural migrant workers reveal that to find an office job with career prospects is difficult for women who have only basic qualifications. Young women from rural China-who have made much effort to become better qualified, such as ZJ and DH (another female participant) in the sample — tend to find themselves gao-bu-cheng, di-bu-jiu (unable to get a higher post but unwilling to take a lower one), due to a lack of elite qualifications and necessary local social capital. Consequently, for rural migrant youths (Nie 2016), and young women in particular, ostensibly legitimate companies, such as those running illegal pyramid schemes, present them with rare money-making and career opportunities (Shi and Cao 2013). Previous research (e.g. Shen and Antonopoulos 2016) and the data in this study seem to suggest that women's involvement in criminal enterprise - pyramid selling here-links with the gendered and class marginalisation.

Notably, the migrant women in this case study were motivated by economic gain, rather than particular or immediate financial need, for engaging in the illicit business, and they also had other incentives. ZJ explained that the job in the criminal firm did provide her with 
opportunities for personal and professional development, which gave her a sense of responsibility, achievement and self-worth:

For me, money was not everything. The company gave me career opportunities... Before it was shut down [by the authority], I was already a jing-li (manager) above 29 ye-wuyuan (ordinary members)... There were many, many good things about this job... I think it could undoubtedly change you and make you a better person. For example, it trained us to be polite, and the job has improved my overall su-zhi (quality). I've certainly developed my managerial, communicational and leadership skills there. Often, I thought that the job attracted me largely because I was learning so much from it... Many of us in the company saw it as a career, rather than a job, because we young people wanted to grow, but there are not many opportunities... [In the company] Every step up made you feel advanced and empowered... In the beginning, you only cared about yourself, but gradually, you started to learn to look after those below you. I felt a strong sense of responsibility and achievement. The higher position you were in, the more sophisticated you felt you were. That was amazing... While working in the company, I carried on studies. Actually, I got my chartered accountant qualification just before that [crackdown by the police]. I loved the company also because everybody was the same... and only xiao-shou-ye-ji (literally 'sales figures', here referring to commissions) mattered...

This self-reflection is striking for two reasons. First, quite clearly, the migrant woman did not seem to have intended to engage in criminality. This makes it difficult to classify some women in criminal enterprise, such as ZJ, as female 'organised criminals', despite the fact that they actively participated in business practices that are outlawed. It appears that in a free market economy, there are increased opportunities for women, albeit many are in the grey and criminal sectors which increase women's opportunities to be involved in crime (Alder 1975; Simon 1975).

Second, illegal pyramid selling, by definition, is predatory and 'organised'. Often, the criminal firms provide training, support and 'career' packages to their employees, for longterm survival, expansion and the maximising of illicit gain. This fact further blurs the line between legitimate and illegitimate businesses. The difference, however, is that in the illegitimate commercial world, promotion and high status tend to go primarily with 'sales figures', as ZJ remarked. Consequently, the usual barriers for rural migrant women in mainstream society — gender and class inequalities — may not effectively apply: whoever achieves a higher sales figure would be in a better position. This means that career advancement becomes achievable for ambitious and able females, who are otherwise disadvantaged in career pursuits due to gender discrimination and a lack of resources. Here, xiao-shou-ye-ji pronounces on the migrant women's personal value and capability. In this context, their employment in the criminal firms gave the migrant women a sense of purpose, career prospects, and raised high their self-esteem, which in turn became a drive and motived them to work harder to recruit more members, increase sales figures and learn more to become more competent career women. However, they mistakenly comprehended the realistic outcome for ordinary members (including themselves) in illegal pyramid selling — namely, the harm of the illicit business.

\section{Rural Migrant Women's Roles in the Illicit Business Practices}

Illegal pyramid selling is often operated by organisations in criminal enterprise. In a previous study on women in the Chinese judiciary (Shen 2017), the female judges noted that illegal 
pyramid selling, inter alia, was prevalent among women offenders who performed actively, and some held leading positions. In the case study, both ZJ and ZYY might be active players in the pyramid schemes, who - in legal term- 'induced' or 'coerced' others to participate in the illicit trade. In the course of doing so, ZYY committed a physical crime.

In the scheme that ZYY was involved in, the participants were living in a compound and not allowed to get out. This is an operational model which is not uncommon in pyramid selling in China (Caixin 2017; Xinhua News 2018b). To perform her role as a supervisor within the scheme, the migrant woman once locked up a newly recruited ye-wu-yuan to prevent him leaving, for which she was later convicted of false imprisonment. For her, 'It was a company practice... I was doing my job and did not know that was a crime'. Given the circumstances, the migrant woman, whilst active, did not seem to be a 'female violent offender', as those in serious criminal groups in China (Shen 2016b).

Unlike ZYY, ZJ was a member, as well as a manager, who 'looked after' 29 ordinary members. According to herself, she was capable of doing the job and enjoyed doing it. The court found ZJ to be an 'organiser' of the pyramid scheme, which she denied. In Chinese law, 'leading' and 'organising' pyramid selling are specifically defined. However, what exactly constitutes 'organising and leading an illegal pyramid scheme' has not reached consensus in Chinese academic circles (see e.g. Chen 2016; Shen 2016a; Yang 2011).

ZJ may be a 'leader', according to the Opinion on the Application of Criminal Law regarding Activities in Pyramid Selling (a statutory interpretation jointly issued in 2013 by the Supreme People's Court, the Supreme People's Procuratorate and the Ministry of Public Security). She admitted that as an operational manager, she had some managerial and coordinative responsibilities. It could be argued that she knew, or ought to have known, that measures, such as recruiting participants and demanding entry fees, are fraudulent (Huang 2009; Yang 2011). However, this view is disputed by other commentators. For example, Zhi and Hong (2015) contended that some higher-level managers, who have 30 or more ye-wuyuan below them, may have no impact on the running of the scheme, are most likely to make a loss in the end and therefore should not be classified as 'organisers' or 'leaders'. ZJ may well fit in this category. In practice, however, the role that a 'manager' played in a pyramid scheme seems to be assumed, rather than assessed on facts. As a result, ZJ-who, admittedly, played a managerial role as a part of her job in the criminal firm - was found by the court to be an 'organiser', convicted and sentenced accordingly.

It appears that the criminal firms, which ostensibly carry out normal business practices, are different from criminal organisations engaging in obvious illegalities in the underworld that Steffensmeier (1983) defined. Accordingly, migrant women's engagement in illegal pyramid selling in China may not be comparable with female penetration of the upper reaches of organised crime (Simpson 1987) or female participation in transnational organised crime (Siegel 2014); nor do they seem to comfortably fit in with women in 'pink-collar crime' (Daly 1989; see also Haantz 2002), given the roles they play in lawbreaking and their motives. In this regard, the case study here serves as a manifestation of complex gender dynamics presented in organised crime.

\section{Gains and Losses of Migrant Women in Illegal Pyramid Selling}

In the case study, migrant women who engaged in the supposedly get-rich-quick business practice found themselves to have lost enormously as a result, as ZJ illustrated: 
What was the bad thing about it [the pyramid scheme]? I saw people who became homeless because they sold their homes to get money to join... When our tuan-dui (literally 'team', referring to the company) was dismantled, we [ordinary members] had absolutely nothing... One day after our company was stopped running, one of my yewu-yuan robbed me. He punched me on the head and forced me to take around 8,000 yuan overdraft to give to him. He also aggressively forced me to write him an i. o. u. (I owe you) in lieu of cash for 50,000 yuan. Thinking about this now still makes me shake and feel sick... I did not report this to the police because it was me who recruited him, when his father was critically ill, and he needed quick money. He borrowed a lot to join...

Earlier, we saw how much this young woman appreciated what she gained from her job in the criminal firm, which confirms the claim that the pyramid schemes tend to attract young people who have limited career opportunities (Nie 2016). The fact is that they may suffer tremendous losses as a consequence of participation in the illicit business. For ZJ, in addition to conviction, incarceration and a criminal record which will have a huge negative impact on her in the future, there were debts, as well as undesirable emotional encounters: a trauma of being a victim of violent crime and a guilty conscience about some of her previous behaviours, as we have seen in her self-reflection.

In fact, neither ZJ nor ZYY made any monetary gain in pyramid selling. Their salary and commissions did not even offset the fees that they paid to join the schemes. ZJ borrowed 70,000 yuan from her parents, who were low-paid migrant workers, and she still owed them more than 40,000 yuan when the company was shut down before she was robbed. ZYY had debts, too. After the scheme collapsed, she returned to work as a sale assistant in a clothing shop prior to her arrest. Clearly, female offenders in pyramid selling in this case were in a worse position than their counterparts in the 'wage-earning employment' elsewhere in a different cultural setting (Daly 1989). In this sense, they were not organisers - the few earners on the top of the criminal pyramid.

Furthermore, it is suggested that without local social ties in cities, rural migrants tend to recruit members through their personal networks (Shi and Cao 2013). This was confirmed in the case study. The data shows that for the migrant women, their losses also included the close relationships that they previously had with their families, relatives and friends, whom they recruited or borrowed money from.

\section{Discussion and Conclusion}

This article concerns female offenders in China, who came to be rural migrant women in the case study, and their experiences in one form of organised crime: illegal pyramid selling. It is worth repeating that the analysis in the article relied largely on data drawn from a small sample; the case study was introduced to illustrate some characteristics of women's criminal behaviour, women's entry into and the role they play in criminal enterprise. The purpose is not to generalise women in organised crime nor in illegal pyramid selling in China, but to make contributions to a better understanding of the 'variable nature of crime' involving women (Daly 1989) to assist any theoretical efforts. The data presented in this article - the case study in particular-have enabled a number of important findings and implications. 
First, female migrant offenders, who share the same socioeconomic and household registration statuses, are diverse in terms of age, education, employment and level of ambition. However, they seem to be 'ordinary' Chinese women who conform to the mainstream gender role: to go out to work in the legitimate, grey or criminal business sector, to support themselves and their families.

Second, the data has suggested that the women offenders in this study more typically committed crime jointly with others, including working in the criminal firms. As we have seen, in the criminal sector, illegalities are sometimes (mis)presented as normal business practices. Criminal enterprise provides not only money-making opportunities but also easy access, to women - here rural migrant women — who often have limited resources and are disadvantaged in the job market and the legitimate business world. The findings also bring to light a link between (migrant) women's entry into criminality and some regulatory crimes that are created to tackle organised criminal operations in complex financial and business settings.

Third, and relatedly, economic gain appears to be a primary incentive for migrant women to involve in lawbreaking - often organised activities - that brings 'quick money', but different rationales, for example, advancement of social status, were cited by the female migrant workers who participated in criminal enterprise. The case study has suggested that women's problems include not only financial need but also everyday frustration as a result of the glaring gap between their ambition and the reality. Women, like men, acquire 'the full respectability' package (Giordano et al. 2002) which is difficult for female rural migrants, who do not have competitive qualifications, nor special skills, to obtain through legitimate channels. Thus, this study lends support to Daly (1989) who argued that women offenders are often motivated by a combination of motives for participation in crime.

Furthermore, the case study presented in the article illustrated migrant women's active agency. As we have seen, female migrants in criminal enterprise were motivated and competent 'modern women' (Wylie 2004), rather than 'sad, pathological' women offenders (Kruttschnitt 2016). It may be said that they made rational choice (Becker 1968) to engage in lawbreaking. On the one hand, 'independent rational agents' (Anderson 2001) are 'able and responsible for taking care of their own needs' (Strassmann 1993: 60). In other words, these women could have rationally chosen not to involve in criminality. On the other hand, they were making choice out of no choice, and their rationalities are gendered. Women's 'rationality' in decision-making may be impacted on by various conditions, including their desire for social approval (England 1989), gender roles and the 'broader dynamics of gender inequality' (Driscoll and Krook 2012).

Finally, this article has demonstrated the active roles that women may play in criminal enterprise. Although the empirical data does not allow a fuller profile of women's position in organised crime to be drawn, it has showed that women do seem to have a place in organised criminal activities and therefore are not merely passive players (Clarke 2014; Siegel 2014). This may be understood as women's reaction to the social conditions they are in and their gendered experience in the internal migration process. To a certain extent, this article, primarily through the case study, provides a manifestation of complex gender dynamics in organised crime.

It is true that a specific group in one geographic context - such as migrant women in China here - cannot define the struggles of women and the cause of female criminality (Arsovsak and Allum 2014), nor can they fully demonstrate women's roles and positions in criminal enterprise. Nonetheless, the more local data and analysis, the better we understand the multifaceted, complex and dynamic nature of female lawbreaking, and women's involvement in organised crime in particular. 
Acknowledgments An earlier version of this article was presented at the UNODC-MPC International Conference on Organised Crime and Gender in July 2018 in Florence, Italy. I would like to thank the United Nations on Drugs and Crime (UNODC) for funding and the audience for useful feedback. I am grateful to Børge Bakken for very helpful comments on a later version. I would also like to thank the anonymous reviewers for suggestions and hope they recognise their influence. The article was finalised during my visit to RegNet, the Australian National University in Canberra from October 2018 to February 2019.

Compliance with Ethical Standards All procedures performed in studies involving human participants were in accordance with the ethical standards of the institutional and national research committee, and with the 1964 Helsinki declaration and its later amendments or comparable ethical standards. Informed consent was obtained from all individual participants included in the study.

Conflict of Interest The author declares that there is no conflict of interest.

Open Access This article is distributed under the terms of the Creative Commons Attribution 4.0 International License (http://creativecommons.org/licenses/by/4.0/), which permits unrestricted use, distribution, and reproduction in any medium, provided you give appropriate credit to the original author(s) and the source, provide a link to the Creative Commons license, and indicate if changes were made.

\section{References}

Aas, K. F., \& Bosworth, M. (2013). The borders of punishment: migration, citizenship and social exclusion. Oxford: Oxford University Press.

Alder, F. (1975). Sisters in crime. New York: McGraw-Hill.

Aldridge, J., \& Medina, J. (2008). Youth gains in an English city: social exclusions, drugs and violence. ESRC end of award report. Swindon: ESRC.

Aliveti, A. (2013). Crimes of mobility: criminal law and the regulation of immigration. London and New York: Routledge.

Allum, F., \& Gilmour, S. (Eds.). (2012). Routledge handbook of transnational organised crime. London and New York: Routledge.

Anderson, E. (2001). Should feminists reject rational choice theory? In L. M. Antony \& C. Witt (Eds.), A mind of one's own. Boulder: Westview Press.

Antonopoulos, G. A. (Ed.). (2016). Illegal entrepreneurship, organised crime and social control: essays in honour of Professor Dick Hobbs. Switzerland: Springer.

Arsovsak, J., \& Allum, F. (2014). Introduction: Women in transnational organised crime. Trends in Organised Crime, 17(1-2), 1-15.

Ashworth, A. (1991). Principles of criminal law. Oxford: Clarendon Press.

Attané, I. (2012). Being a woman in China today: a demography of gender. China Perspectives, 4, 5-15.

Bakken, B. (2005). Introduction: Crime, control and modernity in China. In B. Bakken (Ed.), Crime, punishment, and policing in China. Plymouth: Rowman \& Littlefield Publishers.

Bakken, B. (2018). Introduction. In B. Bakken (Ed.), Crime and the Chinese dream. Hong Kong: Hong Kong University Press.

Batchelor, S. (2009). Girls, gangs and violence: assessing the evidence. Probation Journal, 56, 399-414.

Becker, G. A. (1968). Crime and punishment: an economic approach. Journal of Political Economy, 76(2), 169217.

Brownstein, H. H., Spunt, B. J., Crimmins, S. M., \& Langley, S. C. (1995). Women who kill in drug market situations. Justice Quarterly, 12(3), 473-498.

Caixin (2017). A third death confirmed: In recent days, several incidents involving university graduates who were lured into pyramid schemes. http://china.caixin.com/2017-08-14/101130131.html. Accessed 9 September 2017.

Cartier, C. (2001). Globalizing South China. Oxford: Blackwell.

Chen, X. (2016). The crime of organising and leading the pyramid selling activities: nature and boundary. Tribune of Political Science and Law, 34(2), 106-120.

Cheng, J., Liu, J., \& Wang, J. (2017). Domestic migration, home rentals, and crime rates in China. The Journal of Chinese Sociology, 4, 8. https://doi.org/10.1186/s40711-017-0056-3. 
Chesney-Lind, M. (1989). Girls' crime and women's place: toward a feminist model of female delinquency. Crime \& Delinquency, 35, 5-29.

Chesney-Lind, M. (1993). Girls, gangs and violence: anatomy of a backlash. Humanity and Society, 17(3), 321344.

Chin, K.-L., \& Finckenauer, J. O. (2012). Selling sex overseas: Chinese women and the realities of prostitution and global sex trafficking. New York and London: New York University Press.

China Labour Bulletin (2018). Migrant workers and their children https://clb.org.hk/content/migrant-workersand-their-children. Accessed 8 September 2017.

Chu, C. Y.-Y. (2011). Human trafficking and smuggling in China. Journal of Contemporary China, 20(68), 3952.

Clarke, C. (2014). Gender, crime and criminology. The Manchester Review of Law. Crime and Ethics, 88(3), 88100.

Daly, K. (1989). Gender and varieties of white-collar crime. Criminology, 27(4), 769-794.

Davin, D. (1999). Internal migration in contemporary China. Basingstoke: Palgrave.

Denzin, N. (1978). Sociological methods: a sourcebook (2nd ed.). New York: McGraw-Hill.

Dino, A. (2012). Women and transnational organised crime: the ambiguous case of the Italian Mafias. In F. Allum \& S. Gilmour (Eds.), Routledge handbook of transnational organised crime. London and New York: Routledge.

Driscoll, A., \& Krook, M. L. (2012). Feminism and rational choice theory. European Political Science Review, 4(2), 195-216.

England, P. (1989). A feminist critique of rational-choice theories: implications for sociology. The American Sociologist, 20(1), 14-28.

Fiandaca, G. (Ed.). (2007). Women and the Mafia: female roles in organised crime. New York: Springer-Verlag.

Freitag, G. (2010). Mao a feminist? International Journal of Current Chinese Studies, 1, 159-167.

Giordano, P. C., Cernkovich, S. A., \& Rudolph, J. L. (2002). Gender, crime, and desistance: toward a theory of cognitive transformation. American Journal of Sociology, 107(4), 990-1064.

Glaser, B. G. (2007). All is data. Grounded Theory Review: An International Journal, 2(6). http://groundedtheoryreview.com/2007/03/30/1194/. Accessed 2 Feb 2019.

Global Times (2017). Student deaths from pyramid scheme trigger clampdown http://www.globaltimes. cn/content/1060127.shtml. Accessed 8 September 2017.

Goffman, E. (1959). The presentation of self in everyday life. Edinburgh: The Bateman Press.

Gottschalk, P. (2012). Gender and white-collar crime: only our percent female criminals. Journal of Money Laundry Control, 15(3), 362-373.

Haantz, S. (2002). Women and white collar crime. The National While Collar Crime Center. http://www.nw3 c/org. Accessed 12 May 2018.

Hall, S., Winlow, S., \& Ancrum, C. (2008). Criminal identities and consumer culture: crime, exclusion and the new culture of narcissism. Cullompton: Willan.

Hartley, J. (2004). Case study research. In C. Cassell \& G. Symon (Eds.), Essential guide to qualitative methods in organisational research. London: Sage.

Harvey, D. (2005). A brief history of neoliberalism. Oxford: Oxford University Press.

Hesse-Biber, S. N. (2007). Feminist approaches to mixed-methods research. In S. H. Hesse, Biber, \& P. L. Leavy (Eds.), Feminist research practice. London: Sage.

Hobbs, D. (1988). Doing the business: entrepreneurship, detectives and the working class in the East End of London. Oxford: Oxford University Press.

Huang, T. (2009). The construction of the seventh revised criminal law. People's Procuratorial Semimonthly, 6 , $5-21$.

Jacques, S., \& Wright, R. (2014). A social theory of drug sales, gifts and frauds. Crime \& Deliquency, 60(7), 1057-1082.

Kruttschnitt, C. (2016). The politics, and place, of gender in research on crime. Criminology, 54(1), 8-29.

Layder, D. (2013). Doing excellent small-scale research. London: Sage.

Li, C. (1996). Surplus rural labourers and internal migration in China: current status and future prospects. Asian Survey, 36(11), 1122-1145.

Liu, J. (2005). Crime patterns during the market transition in China. British Journal of Criminology, 45, 613-633.

Liu, S. (2011). Passage to Manhood: youth migration, heroin, and aids in southwest China. Stanford, California: Stanford University Press.

Liu, M. (2012). Chinese migrant women in the sex industry: exploring their paths to prostitution. Feminist Criminology, 7(4), 327-349.

Liu, Q., \& Peng, J. (2012). The report on cases involving female offenders. Legal System and Society, 7, 167168. 
Lo, T. W., \& Jiang, G. (2006). Inequality, crime and the floating population in China. Asian Journal of Criminology, 1(2), 103-118.

Marshall, I. H. (Ed.). (1997). Minorities, migrants, and crime. London: Sage.

Melossi, D. (2015). Crime, punishment and migration. London: Sage.

Merton, R. K. (1938). Social structure and anomie. American Sociological Review, 3, 672-682.

Miller, J. (1998). Up it up: gender and the accomplishment of street robbery. Criminology, 36(1), 37-66.

Miller, J. (2001). One of the guys: girls, gangs and gender. New York and Oxford: Oxford University Press.

Miller, T. (2012). China's urban billion: the story behind the biggest migration in human history. London and New York: Zed Books.

Naughton, R. J. (2007). The Chinese economy: transitions and growth. Hong Kong: SNP Best-set Typesetter Ltd.

Ngai, P. (2007). Gendering the dormitory labour system: production, reproduction, and migrant labour in south China. Feminist Economics, 13(3-4), 239-258.

Nie, L. (2016). Research into the patterns of the law against pyramid selling involving university graduates from a contemporary legal perspective. Journal of Jilin Engineering Normal University, 32(11), 66-68.

Palidda, S. (Ed.). (2011). Racial criminalization of migrants in the 21st century. Surrey: Ashgate.

Pizzini-Gambetta, V. (2008). Women and the mafia: a methodology minefield. Global Crime, 9(4), 348-353.

Pratt, A., \& Valverde, M. (2002). From deserving victims to "Masters of Confusion": redefining refugees in the 1990s. Canadian Journal of Sociology, 27(2), 135-161.

Rofel, L. (2007). Desiring China: experiments in neoliberalism, sexuality, and public culture. Durham: Duke University Press.

Sharpe, G. (2012). Offending girls: young women and youth justice. London: Routledge.

Shen, A. (2015). Offending women in contemporary China: gender and pathways into crime. Basingstoke: Palgrave.

Shen, C. (2016a). Conceptualise illegal pyramid selling and regulation through criminal law. Journal of Hunan Administration Institute, 5, 78-82.

Shen, A. (2016b). Female membership in the black-society style criminal organisations: evidence from a female prison in China. Feminist Criminology, 11(1), 69-90.

Shen, A. (2017). Women judges in contemporary China: gender, judging and living. London: Palgrave.

Shen, A. (2018). Internal migration, crime and punishment in contemporary China: an inquiry into rural migrant offenders. Switzerland: Springer.

Shen, A., \& Antonopoulos, G. A. (2016). Women in criminal market activities: findings from a study in China. In G. A. Antonopoulos (Ed.), Illegal entrepreneurship, organised crime and social control. Switzerland: Springer.

Shen, A., \& Winlow, S. (2013). Women and crime in contemporary China: a review essay. International Journal of Comparative and Applied Criminology, 38(4), 327-342.

Shi, B., \& Cao, K. (2013). Discuss illegal pyramid selling. Legality Vision, 4, 233-233.

Siegel, D. (2014). Women in transnational organised crime. Trends in Organised Crime, 17(1-2), 52-65.

Simon, R. J. (1975). Women and crime. Lexington: Lexington Books.

Simpson, S. S. (1987). Women in elite deviance: a grounded theory. Montreal: Paper presented at the annual meeting of the American Society of Criminology.

Steffensmeier, D. (1983). Organisation properties and sex-segregation in the underworld: building a sociological theory of sex differences in crime. Social Forces, 61(4), 1010-1032.

Steffensmeier, D., \& Allen, E. (1996). Gender and crime: toward a gendered theory of female offending. Annual Review of Sociology, 22(1), 459-487.

Strassmann, D. (1993). Not a free market. In M. A. Ferber \& J. A. Nelson (Eds.), Beyond economic man. Chicago: University of Chicago Press.

Sun, I., Luo, H., Wu, Y., \& Lin, W.-H. (2016). Strain, negative emotions, and level of criminality among Chinese incarcerated women. International Journal of Offender Therapy and Comparative Criminology, 60(7), 828846.

Tonry, M. (Ed.). (1997). Ethnicity, crime, and immigration: comparative and cross-national perspectives. Chicago and London: The University of Chicago Press.

Wang, H. (2003). China's new order: social, politics and economics, edited and translated by R. Huters. Cambridge: Harvard University Press.

Willis, J. (2007). Foundations of qualitative research: interpretive and critical approaches. Thousand Oaks: Sage.

Withrow, B. L. (2014). Research methods in crime and justice. New York: Routledge.

Wright, A. (2006). Organised crime. Cullompton: Willan.

Wylie, C. (2004). Femininity and authority: women in China's private sector. In A. E. McLaren (Ed.), Chinese women - living and working. London: RoutledgeCurzon. 
Xinhua News (2018a). China woos migrant workers home for rural development http://www.xinhuanet. com/english/2018-02/24/c_136997089.htm. Accessed 5 May 2018.

Xinhua News (2018b). Investigation into illegal pyramid selling involving university students. http://dl. xinhuanet.com/ztjn/daxueshengchuanxiao/. Accessed 5 May 2018.

Xinhua News (2018c). Guangzhou police cracked down criminal group involving in the Yun-lian-hui pyramid scheme. http://www.xinhuanet.com/2018-05/09/c_1122805631.htm. Accessed 10 May 2018.

Xu, J. (2009). The robbery of motorcycle taxi drivers (Dake zai) in China. British Journal of Criminology, 49(4), $491-512$.

Xu, J. (2014). Urbanisation and inevitable migration: crime and migrant workers. In L. Cao, I. Y. Sun, \& B. Hebenton (Eds.), The Routledge handbook of Chinese criminology. Oxon: Routledge.

Yan, Y. (2009). The individualisation of Chinese society. Oxford: Berg.

Yang, W. (2011). Research into several issues in relation to organising and leading pyramid schemes. Cross-Strait Legal Science, 3, 47-52.

Yin, R. (2009). Case study research: design and methods (4th ed.). Thousand Oaks: Sage.

Zhang, L. (2001). Contesting crime, order, and migrant spaces in Beijing. In N. N. Chen, C. D. Clark, S. Z. Gottschang, \& L. Jeffery (Eds.), China urban: ethnographies of contemporary culture. Durham and. London: Duke University Press.

Zhang, L., Messner, S. F., \& Liu, J. (2007a). A multilevel analysis of the risk of household burglary in the city of Tianjin, China. British Journal of Criminology, 47(6), 918-937.

Zhang, S. X., Chin, K. L., \& Miller, J. (2007b). Women's participation in Chinese transnational human smuggling: a gendered market perspective. Criminology, 45(3), 699-733.

Zhao, S., \& Kipnis, A. (2000). Criminality and policing of migrant workers. The China Journal, 43, 101-110.

Zheng, T. (2009). Red lights: the lives of sex workers in postsocialist China. Minneapolis: University of Minnesota Press.

Zheng, T. (2014). Prostitution and human trafficking in China. In L. Cao, I. Y. Sun, \& B. Hebenton (Eds.), The Routledge handbook of Chinese criminology. Oxon: Routledge.

Zhi, G., \& Hong, L. (2015). Research into legal issues about organising and leading illegal pyramid schemes and countermeasures. Criminological Research, 5, 67-78.

Publisher's Note Springer Nature remains neutral with regard to jurisdictional claims in published maps and institutional affiliations. 